\title{
Applicability of the free field Sustained Auditory Attention Ability Test (SAAAT)
}

\section{Aplicabilidade do teste da habilidade de atenção auditiva sustentada - THAAS em campo livre}

\author{
Mariza Ribeiro Feniman', Ariane Cristina Sampaio Rissatto², José Roberto Pereira Lauris³ ${ }^{3}$ Maria Fernanda Capoani Garcia Mondelli". \\ 1) Post-Doctorate in Audiology - Univeristy of Cincinnati, Ohio, USA. Head of Department of Speech-FOB-USP. Professor, Department of Speech Pathology, FOB / \\ USP. \\ 2) Master's Degree in Speech Therapy, FOB / USP. Speech. \\ 3) Freedom of teaching. Associate Professor, Department of Pediatric Dentistry, Orthodontics and Public Health, Faculty of Dentistry of Bauru, University of Sao Paulo, \\ FOB / USP \\ 4) Ph.D. in Communication Disorders at HRAC / USP. Professor, Department of Speech, FOB / USP. \\ Institution: Faculty of Dentistry of Bauru - University of Sao Paulo. \\ Bauru / SP - Brazil \\ Mailing address: Mariza Ribeiro Feniman - Octávio Pinheiro Brizola Mall, 9-75 - Vila Universitária - Bauru / SP - Brazil - Zip-code: 17012-901 - E-mail: \\ mfernandamondelli@hotmail.com \\ Article received in April 28, 2011. Article approved in June 25, 2011.
}

\section{SUMMARY}

Introduction: The attention is an underlying neuropsychology function to all the cognitive processes. The auditory deficiency compromises the normal development of the child, modifying diverse auditory abilities, including the attention.

Objective: to compare the performance of children in the Test of the Ability of Auditory Attention Support, as for the different forms of application (auricular phones and free field), sort and, application order.

Method: 40 children (7 years old) voluntary with typical development had participated, divided in two groups: G1 and G2, composites of 20 children each. The application of the THAAS in the G1 if gave first with auricular phones and after that in free field and the G2 the process was inverse. The evaluation consisted in: specific questionnaire, auditory tests and application of the THAAS.

Results: It did not have significant difference how much to the sort. For the THAAS with phones, the G1 presented greater amount of errors of carelessness and total punctuation. For the THAAS in field it had a significant difference of the G2 for the monitoring decrease. How much to the application form, the G1 demonstrated a bigger number of errors when it was used phones. The G2 did not demonstrate difference.

Conclusion: It had viability in the application of the THAAS in Free Field, being able to be adopted the same used normative values for the conventional way of evaluation.

Keyword: hearing, attention, child.

\section{RESUMO}

Introdução: A atenção é uma função neuropsicológica subjacente a todos os processos cognitivos. A deficiência auditiva compromete o desenvolvimento normal da criança, alterando diversas habilidades auditivas, incluindo a atenção. Objetivo: comparar o desempenho de crianças no Teste da Habilidade de Atenção Auditiva Sustentada-THAAS, no que se refere às diferentes formas de aplicação (fones auriculares e campo livre), gênero e, ordem de aplicação.

Método: participaram 40 crianças ( 7 anos) voluntárias com desenvolvimento típico, divididas em dois grupos: G1 e G2, compostos de 20 crianças cada. A aplicação do THAAS no G1 se deu primeiramente com fones auriculares e em seguida em campo livre e no G2 o processo foi inverso. A avaliação constituiu-se em: questionário específico, testes auditivos e aplicação do THAAS.

Resultados: Não houve diferença significante quanto ao gênero. Para o THAAS com fones, o G1 apresentou maior quantidade de erros de desatenção e pontuação total. Para o THAAS em campo houve uma diferença significante do G2 para o decréscimo de vigilância. Quanto à forma de aplicação, o G1 demonstrou um número maior de erros quando foi utilizado fones. O G2 não demonstrou diferença.

Conclusão: Houve viabilidade na aplicação do THAAS em Campo Livre, podendo ser adotado os mesmos valores normativos usados para o modo convencional de avaliação. Palavras-chave: audição, atenção, criança. 


\section{INTRODUCTION}

The existence of an auditory deficiency by itself compromises the normal development of a child, a time that the sensorial privation can generate alterations in diverse auditory abilities, including atention (1). Thus, despite carrying children of this type of deficiency are duly inserted in a process of auditory rehabilitation, either making use of device of individual sonorous amplification (AASI) or of the cochlear implantation (IC), beyond the speech therapy, these children can be citizens still to other problems, as those related to the auditory attention.

Identifying and to give attention to acoustic and phonetic aspects of the linguistics standards are essential for the acquisition and the development of the language, as much for children deficient normal listeners how much for the auditory ones. With the ability of deficit attention, these aspects can meet wronged, intervening with the pertaining to school, cognitive and social performance of children (2).

The attention is a neuropsychological basic function that is underlying to all the cognitive processes. It can be defined as the capacity of the individual to select and to focus its mental processes in some aspect of the internal or external environment, answering predominantly to the stimulations that it are significant and inhibiting answers to excessively stimulus $(3,4)$.

The literature reported that the supported attention and the monitoring are some of the processes that characterize the attention ability. The attention does not constitute an only process.

The supported attention is defined as the capacity to keep the attentional focus in one determined stimulation, for a period of time, to execute a task $(4,5)$. The monitoring is the ability to remain prepared for an intermittent signal.

The use of the Test of Ability of Auditory Attention Supported-(THAAS) $(6,7)$, carried through in conventional way, with auricular phones, has shown an efficient and promising tool to evaluate this important ability in the different clinical entities, auditory deficiency (8), cleft palate fiction (9), velocardiofacial syndrome (10) and phonological upheaval (11).

The THAAS is based on the test of continuous performance, ACPT-Auditory Continuous Performance Test (12), which is used clinically to measure the auditory attention, thus, requires that the citizen focuses and supports the attention during all the test and answers for a target stimulation previously specified (13).

With intention to evaluate this important auditory ability in children who make use of electronic devices, as well as the those that are not collaborators in the use of auricular phones, during the accomplishment of a behavioral evaluation; throughout years of clinical experience with this population, it was thought about verifying the applicability of the THAAS not only using its conventional way.

The objective of this work is to compare the performance of children in the THAAS as for the different forms of presentation, with auricular phones (conventional way) and in free field; to the sort and, to the application order, aiming at its posterior application to those that do not allow the rank of auricular phones, that make use of AASI or IC.

\section{MetHOD}

This work was developed in the Clinic of Phonoaudiology of the College of Odontology of Bauru of the University of São Paulo, having been submitted to the approval for the Committee of Ethics in Research in Human Beings under seeming in the $n^{\circ} 157 / 2007$.

In order to select the casuistry for this study, that is, children of seven years the seven years and 11 months, with absence of complaint and/or auditory alteration, without intellectual commitment, and description of carelessness, were made contact with pertaining to school parents, in order to carry through invitation its children, pertaining to this age to participate of the study. After the acceptance the children had been perhaps placed and paired the next possible one how much to the sort.

The chosen age must it the fact of being an age of great importance for the learning, period of literacy, whose ability of attention becomes essential.

After the reading and the Signature of the Term of Free and Clarified Assent, the parents and/or responsible had been submitted to the attention questionnaire, aiming at to get information how much to the personal dates; how much to the presence of neurological problems or other deficiencies; how much to the auditory health, the mannering and academic aspects related to the manifestation or complaints of carelessness of the child.

After, all the children had been submitted to the visual inspection of the acoustic meatus, to the immittance testing, by means of the use of Image Resources GSI Tympstar, to the Audiometry Preliminary Tonal, using the 
audiometer Siemens SD50, with auricular phones and in cabin acoustics; to the Threshold of reception of speech/ SRT and to the Audiometric in Free Field, carried through in the audiometer Clinical Audiometer AC 40.

It was considered as criterion of inclusion in the present study:

- Equal age has seven years the seven years and 11 months.

- Absence of auditory complaints or condition of the superior aerial ways.

- Absence of neurological problems or other deficiencies.

- Up to seven questions designated in the attention questionnaire.

- Absence of strange body and/or excess of wax in the external ear.

- Tympanometric Normal Curve - Type A (14).

- Audiometric threshold up to 15 dBNA (15), with compatible SRT.

- Attainment of a total scores of errors (total punctuation) equal or inferior the 36 and decrease of lesser monitoring that eight in the THAAS (conventional).

Of the total of 106 met children, data of 40 of them could have been computed in this work, in view of the established criteria of inclusion. The participation of these 40 children was determined as being significant sampling number for the development of the research, being, therefore, this the minimum number of children predetermined will participate of this study.

Thus, was performed a randomized study in the 40 voluntary children, being 11 of masculine sort and nine of the feminine one, as much for the G1 as for the G2, applying the THAAS in different sequences of accomplishment. In the first half ( 20 children), this test in the conventional way was applied first, in cabin acoustics and with auricular phones. Later, after 15 days of interval (time suggested for Kerth (12)), the test was reapplied then, in the same children, however, in free field, being this called Group in study one (G1); e in the other half (20 children) the process was the inverse one, first the THAAS in free field was applied, and after the interval of minimum time of 15 days, the test was applied again, however, of this second time in cabin acoustics, with auricular phones, determined as Group in study two (G2) (Figure 1).

The inquiry protocol was composed of the mannering test (Test of Ability of Auditory Attention Supported THAAS) that evaluates the ability of supported auditory attention, presented in two forms, with auricular phones (conventional way) and in free field.

The THAAS (6) consists in a method of objective information to describe and to evaluate the behavior of

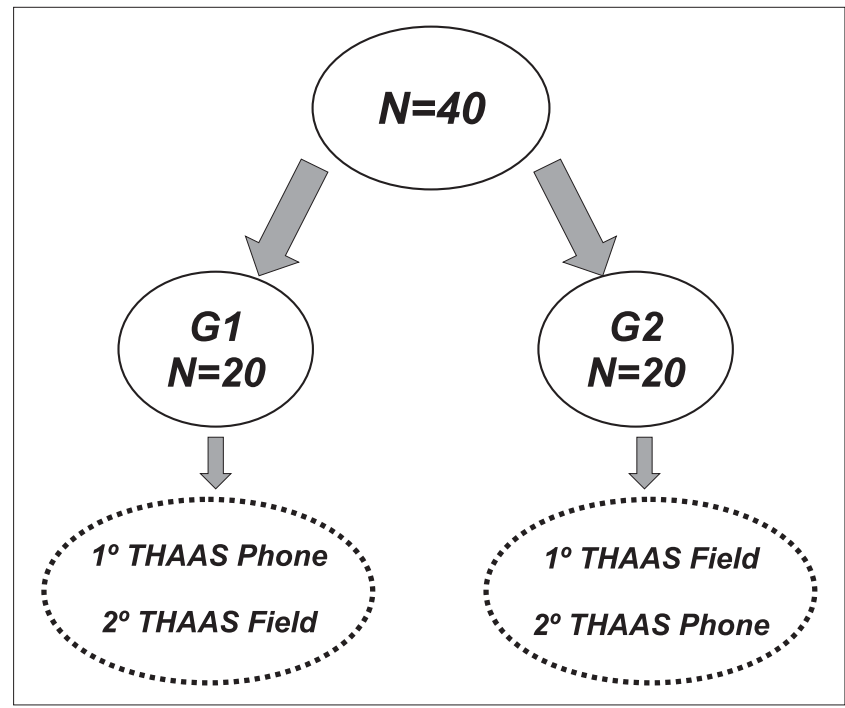

Figure 1. Project of distribution of children in the research and formation of the groups.

auditory attention in children, by means of the evaluation of the ability of the child to listen to auditory stimulations during a period of drawn out time and to only answer for a specific stimulation. It is a task of auditory monitoring, indicated for the correct answers for the specific linguistics tracks, and serves to measure the attention supported, indicated for the ability of the child in keeping the attention and concentration in the task for a period of drawn out time. They consist of the binaural and diotic presentation of a list of 21 monosyllabic words (foot, yes, flower, goal, train, sea, sun, want, badly, wool, ox, mine, salt, father, gas, go, sky, not, already, dust and one), which are repeated and rearranged randomly, forming a list of 100 words including the 20 occurrences of the white word "not". This list, recorded in $\mathrm{CD}$, is presented six times uninterruptedly, totalizing, of this form, 600 monosyllabic words, with duration of 10 minutes.

The presentation of the test gave to an intensity of $50 \mathrm{dBNS}$, considering the average of the auditory aerial thresholds $(500 \mathrm{~Hz}, 1 \mathrm{kHz}$ and $2 \mathrm{kHz})$ of each ear.

Each child was instructed verbally by the appraiser of whom she would hear a list of words and that all time would have to raise the hand that heard the word "not".

Previously to the first presentation of the list of 600 words of test THAAS, was presented to the child, for practical, a recorded sample in $\mathrm{CD}$, of 50 monosyllabic and presented words, also, uninterruptedly, being 10 of them the word "not", made use in random way. After the child to only have understood the task, the test then was applied. 
The application of the test gave by means of a Disc Man $40+$ sec. virtual antishock of Toshiba, with exit line out, connected to an audiometer, Audiometer SD 50 for application with auricular phones, and the audiometer Clinical Audiometer AC40 for application in free field.

For application of the THAAS in free, take care of field with regard to the treat environment acoustically was preset and kept the angles of incidence of the signal in all the measures, being that the child was located $60^{\circ}$ Azimuth of the two boxes of sound laterally, with distance of 2 meters, forming an equilateral triangle, thus the incidence of the sound was same for both the ears; beyond the researcher to have kept intent to the physical and psychological conditions of the child during the test (Figure 2).

The data had been analyzed in view of the answers gotten in the THAAS with auricular phones in cabin acoustics and free field.

To determine the performance of the child in this test, the errors of carelessness had been considered, when the child did not raise the hand in reply to the white word ("not"); errors of impulsiveneness, when the child raise the hand for another word on the contrary of the white word ("not"); the counting of the number of errors of carelessness increased of the number of errors of impulsiveneness allowed to get the total punctuation of errors of the THAAS. The monitoring was gotten calculating the number of correct answers for the word "not" during the sequence of the six presentations. The calculation of this measure was necessary, in order to verify the decrease of the monitoring, i.e., the decline in the attention that occurred with the time during the monitoring task, that will be gotten calculating the number of correct answers for the word "not" in $1^{\text {a }}$ presentation not deducting the number from correct answers for 6 a presentation. The difference found between these two numbers is called surveillance decrease.

Following given normative (6) for the age of seven years the waited average value for the errors of carelessness is 31 , for the impulsiveneness is eight, for the total punctuation is 36 and for the decrease of monitoring a lesser value that eight.

For the analysis of the results, the blind double character was adopted, not being possible to the researcher to identify the test application way (with phones or in free field) in order to prevent that the results have been vitiated or tendentious.

Following the considered objective, the results of the THAAS had been analyzed and computed in order to become fulfilled later the comparison of the gotten data intra-citizens (with the same children) at two moments: $1^{\circ}$

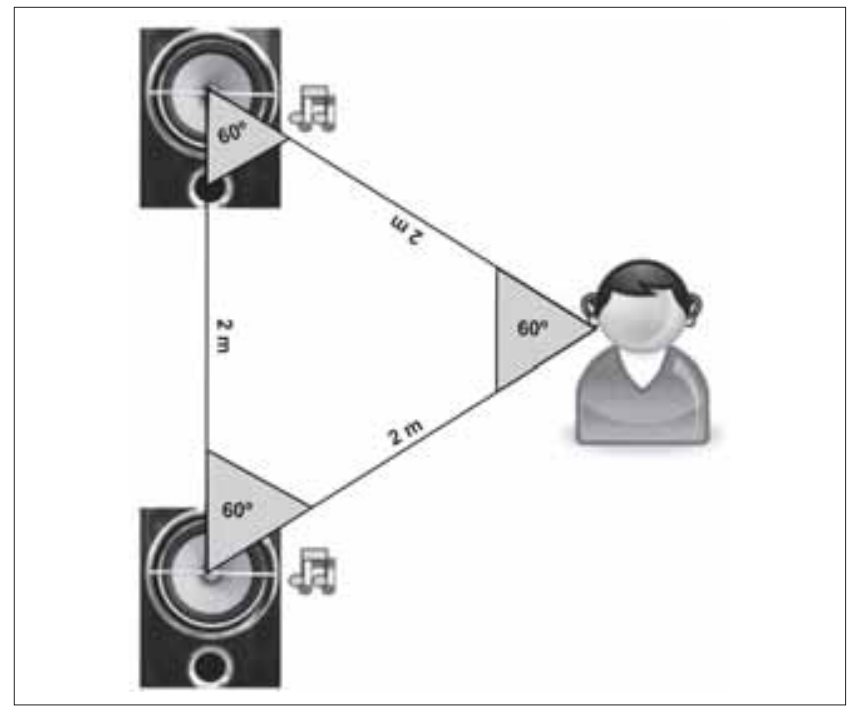

Figure 2. Project of evaluation in free field.

in the presentation with auricular phones in cabin acoustics and $2^{\circ}$ in free field (not necessarily in this same order).

To evaluate the performance between the groups and sort, the used statistical tests had been the Analysis of Variance (ANOVA) and the Tukey test. For these analyses, was used the Pacotico CD, version 4.6 (16).

The quantitative variable had been represented by average, medium, shunting line standard and minimum and maximum values. In all the tests, the level of rejection of the adopted hypothesis of nullity was of $5 \%(p<0,05)$.

\section{RESULTS}

Following the considered objectives, Table 1 presents the performance (average and shunting line standard) of the children of the two showed groups, in the application of the THAAS in the situation with auricular phones and free field.

The variance analysis to three criteria did not present significant difference enters the sorts in none of the conditions or groups ( $p>0,05)$. Therefore was transferred to analyze the data without separation between sorts.

Table 2 presents the comparison between forms in the same condition when applied on the first time, and the Table 3, when applied in the second time.

Thus, when applied for the first time only had difference between phone and field in the carelessness $(\mathrm{p}=0,049)$, not having difference in the second application. 
Table I. General performance for the THAAS for application condition (Phone or Field), sort and group.

\begin{tabular}{|c|c|c|c|c|c|c|c|c|c|}
\hline \multirow{3}{*}{ Form } & \multirow{3}{*}{ Behavior } & \multicolumn{4}{|c|}{ Gl } & \multicolumn{4}{|c|}{ G2 } \\
\hline & & \multicolumn{2}{|c|}{ Female } & \multicolumn{2}{|c|}{ Male } & \multicolumn{2}{|c|}{ Female } & \multicolumn{2}{|c|}{ Male } \\
\hline & & media & $\mathrm{dp}$ & media & $\mathrm{dp}$ & media & $\mathrm{dp}$ & media & $\mathrm{dp}$ \\
\hline \multirow[t]{4}{*}{ Phone } & Oversight & 17,2 & 10,7 & 15,4 & 6,4 & 11,9 & 8,9 & 7,0 & 9,1 \\
\hline & Impulsiveness & 3,7 & 2,2 & 4,0 & 2,0 & 1,3 & 2,1 & 4,4 & 4,9 \\
\hline & Total of errors & 20,9 & 10,9 & 19,4 & 7,4 & 13,2 & 9,7 & 11,4 & 9,6 \\
\hline & Decrease of monitoring & 1,5 & 1,6 & 1,6 & 2,1 & 1,7 & 1,6 & 0,7 & 1,9 \\
\hline \multirow[t]{4}{*}{ Field } & Oversight & 9,9 & 10,6 & 4,6 & 2,9 & 12,3 & 8,7 & 9,8 & 6,0 \\
\hline & Impulsiveness & 3,7 & 2,2 & 4,2 & 4,2 & 4,0 & 2,6 & 6,0 & 6,2 \\
\hline & Total of errors & 13,6 & 10,8 & 8,8 & 6,1 & 16,3 & 8,7 & 15,8 & 10,3 \\
\hline & Decrease of monitoring & 0,7 & 1,2 & 0,0 & 0,5 & 2,3 & 2,8 & 2,7 & 2,1 \\
\hline
\end{tabular}

Table 2. Comparison between Phone and Field when the same ones are applied on the first time.

\begin{tabular}{lcccccc}
\hline Measurement & \multicolumn{2}{c}{ GIPhone } & \multicolumn{2}{c}{ G2 Field } & dif. & P \\
& media & dp & media & dp & & \\
\hline Oversight & 16,4 & 8,8 & 11,2 & 7,5 & $-5,3$ & 0,049 * \\
Impulsiveness & 3,9 & 2,1 & 4,9 & 4,6 & 1,1 & 0,356 ns \\
Total of errors & 20,3 & 9,3 & 16,1 & 9,2 & $-4,2$ & $0,159 \mathrm{~ns}$ \\
Decrease of monitoring & 1,5 & 1,8 & 2,5 & 2,5 & 1,0 & $0,175 \mathrm{~ns}$ \\
\hline
\end{tabular}

* - statistical significant difference $(\mathrm{p}<0,05)$.

ns - statistical not significant difference.

Table 3. Comparison between Phone and Field when the same ones are applied in the second time.

\begin{tabular}{lcccccc}
\hline Measurement & \multicolumn{2}{c}{ GI Field } & \multicolumn{2}{c}{ G2 Phone } & dif. & P \\
& media & dp & media & dp & & \\
\hline Oversight & 7,5 & 8,4 & 9,7 & 9,1 & 2,2 & $0,433 \mathrm{~ns}$ \\
Impulsiveness & 4,0 & 3,2 & 2,7 & 3,9 & $-1,3$ & $0,271 \mathrm{~ns}$ \\
Total of errors & 11,5 & 9,1 & 12,4 & 9,4 & 1,0 & $0,747 \mathrm{~ns}$ \\
Decrease of monitoring & 0,4 & 1,0 & 1,3 & 1,7 & 0,9 & $0,066 \mathrm{~ns}$ \\
\hline
\end{tabular}

* - statistical significant difference $(\mathrm{p}<0,05)$.

ns - statistical not significant difference.

Table 4. Comparison between first Field when applied (G2) with Field when applied in according to place (GI).

\begin{tabular}{lcccccc}
\hline Measurement & $\begin{array}{c}\text { G2 Field } \\
\text { media }\end{array}$ & dp & $\begin{array}{c}\text { GI Field } \\
\text { media }\end{array}$ & dp & dif. & $p$ \\
\hline Oversight & 11,2 & 7,5 & 7,5 & 8,4 & $-3,7$ & $0,156 \mathrm{~ns}$ \\
Impulsiveness & 4,9 & 4,6 & 4,0 & 3,2 & $-1,0$ & $0,450 \mathrm{~ns}$ \\
Total of errors & 16,1 & 9,2 & 11,5 & 9,1 & $-4,6$ & $0,120 \mathrm{~ns}$ \\
Decrease of monitoring & 2,5 & 2,5 & 0,4 & 1,0 & $-2,1$ & 0,001 * \\
\hline
\end{tabular}

* - statistical significant difference $(p<0,05)$.

ns - statistical not significant difference.

Comparison also was carried through between first and second time, in the same form of application (Tables 4 and 5).

For the condition in free field there was a general trend of reduction of the values in the second time, however with significance statistics only forthe monitoring decrease $(p=0,001)$.
For the condition with Phone also had a general trend of reduction of the values in the second time, however with significance statistics only for the carelessness $(p=0,024)$ and Total of errors $(p=0,011)$.

As for the interval of covered time the application of the THAAS enters in phone and in field in the G1 and 
Table 5. Comparison between first Phone when applied (GI) with Phone when applied in according to place (G2).

\begin{tabular}{|c|c|c|c|c|c|c|}
\hline Measurement & $\begin{array}{c}\text { GI Phone } \\
\text { media }\end{array}$ & $d p$ & $\begin{array}{l}\text { G2 Phone } \\
\text { media }\end{array}$ & $d p$ & dif. & p \\
\hline $\begin{array}{l}\text { Oversight } \\
\text { Impulsiveness } \\
\text { Total of errors } \\
\text { Decrease of monitoring }\end{array}$ & $\begin{array}{c}16,4 \\
3,9 \\
20,3 \\
1,5\end{array}$ & $\begin{array}{l}8,8 \\
2,1 \\
9,3 \\
1,8\end{array}$ & $\begin{array}{c}9,7 \\
2,7 \\
12,4 \\
1,3\end{array}$ & $\begin{array}{l}9,1 \\
3,9 \\
9,4 \\
1,7\end{array}$ & $\begin{array}{l}-6,7 \\
-1,2 \\
-7,9 \\
-0,3\end{array}$ & $\begin{array}{l}0,024 \text { * } \\
0,249 \text { ns } \\
0,01 I^{*} \\
0,660 \text { ns }\end{array}$ \\
\hline
\end{tabular}

* - statistical significant difference $(\mathrm{p}<0,05)$.

ns - statistical not significant difference.

the G2, a maximum of 360 and a minimum of 25 days for the G1 and 75 and 15 days for the G2 were verified, revealing more heterogeneous for the G1 and more homogeneous for the G2.

\section{DISCUSSION}

The absence of found significant difference for the sorts is concordant with works found in specific literature $(17,18,6,8,19)$. On the other hand, research demonstrates performance of the feminine sort better when compared with masculine (20-24), fact this explained due to bigger difficulty to diagnosis children of the feminine sort for the attentional deficit, for present less exacerbated behaviors of what the masculine sort (25). Research refer (26) that the ability of auditory attention of women is better because they obtain to keep it, exactly for a stimulation without meaning as the noise. Other studies $(27,28)$ had found worse performance for the feminine sort. Authors (20) had described, still, that the difference with regard to the attention between the sorts diminishes with the advance of the age.

The THAAS is a based national test in an American test, Auditory Continuous Performance Test (ACPT), used in a series of clinical studies (29-31,13, 32-34). Keith (12) verified by means of this test $(A C P T)$ that the errors of carelessness had been three times more frequent than the errors of impulsiveneness. Feniman (6) found ratio average of 3,5 . In the present study in the $\mathrm{G} 1$ the ratio found for the comparative errors of carelessness to the ones of impulsiveneness was similar, except for the situation of application in free field in the masculine sort, in which was verified average of errors of equal carelessness the 4,6 and errors of equal impulsiveneness the 4,2 (Table 1).

The difference found between the G1 and the G2 (with regard to the gotten values adding the averages of the number of errors for phone and field) possibly must to the difference of the interval of covered time between the two forms of application.

Although in both the groups the performance of the children has been better in the second presentation of the test, comparing the performance of the G1 with the $\mathrm{G} 2$ with phone and in free field (Table 1), considering the two presentations, the scores of G2 had values next than in the G1, what it could be explained being based on the hypothesis of the difference of interval of time in the two groups, or, also, it can be that has been to perhaps.

Being based on the gotten results, in the comparison between the groups, it was observed that the G1 had greater number of errors that the $\mathrm{G} 2$ in the application with phone for the entire item of the THAAS, being statistical significant for carelessness and total of errors.

On the basis of the findings of the G1, could be thought that the situation of application of the test in free field acted as facilitator of the test, for having been verified better performance of the children. Thus being, the cabin acoustics used for application of the test with phones was reason of distraction in the children, therefore there was little visual contact with the appraiser in this situation, differently in the situation in free field where it has greater proximity in the situation, a time that the environment acoustically treated was the same for the appraiser and the child. In the application with phones, the child was evaluated in a cabin acoustics, in which the appraiser met of the side of is, observing the child only for a small glass viewfinder, what he could diminish the motivation of the child during the evaluation situation.

However, as in the G2, in which the application of the THAAS occurred first in field, and in the moment with phone and the children they had presented performance with phone better of what in field, was observed the same performance standard (better in the second application) Tables 2 and 3 . 
The same can be thought for the comparison between the groups for application of the THAAS in free field, a time that the G2 presented more errors that the G1 for all the item of the test (being this difference significant statistical for the monitoring decrease). Valley to stand out that in the G2 the first application was in free field and in the G1 was the second application that occurred in free field, where the children could already be made familiar to the test.

In the accomplishment of the test - retest of the ACPT gotten for KeITH (12), this did not verify significant difference statistics between first and the second time where the test was applied (intra-citizens). This proximity between scores joined in the retest give greater trustworthiness to the test. It is standed out, still, that the two applications of the test in the work of KeIтH (12) had been gotten with the same form of presentation (only with phones), differently of the present research.

These data are in agreement with the findings of reseracher (18) that had verified a better average performance in the second presentation of a list that evaluated selective attention, believing that this fact must the learning effect.

In neural terms, the performance of certain trained activities previously (or perhaps of ampler form, the context) must pre-activate the neural nets, in way that the fruit of its processing pass to have priority for the attentional systems (35).

The use of a fortuitous or random process in order to grant to the participants of a determined studies the same probability to receive the intervention to be tested or the control, revolutionized the practical clinic when having been used for the first time in the end of the 40's. More recently, the randomized clinical assays come being described as the "standard-gold" in the evaluation of therapeutically questions in health. By means of this type of study is scrambled the probability to get tendentious data in the research.

The beginning of randomization is simple, and it bases on the fact from that the participants of determined study have the same probability to receive in such a way the intervention to be tested how much the control (36). If this principle is respected and carried through in adjusted way, the randomization reduces the risk of bias quality controls (or bias), producing a balance between the diverse factors of risk that can influence in the clinical outcome to be measured (37).

It is believed that the randomization of this study was the process that assented these findings, allowing concluding about the learning effect, as they had demonstrated the results.

However, authors (38), studying the attention in children, verified that with the repetition of the test the children who had been better at a first moment, had become more impulsive and less intent in the second presentation, being opponent with the results verified for the $G 1$ as for the G2, seen one better performance in the second application of the test, justifying for the effect of the learning.

Agreeing to the results of this work, the application of the P300 revealed viable in free field, not presenting significant differences statistical for the sort and way of presentation of test (39).

\section{CONCLUSION}

The performance of children in the THAAS revealed similar in the different applied forms of presentation, however, better scores had been observed in the second presentation.

The children of the feminine sort and the masculine had not differed score of the THAAS for the two forms of presentation.

The test demonstrated to applicability in both the forms.

\section{BibLIOGRAPHIC RefERENCES}

1. US Preventive Services Task Force. Universal screening for hearing loss in newborns: US Preventive Recommendation Statement. Pediatrics. 2008, 122(1):1438.

2. Manrique MJ, Huarte A. Hipoacusias. Surdez. In: ChevrieMuller C, Narbona J. A linguagem da criança: aspectos normais e patológicos. $2^{\mathrm{a}}$ ed. Porto Alegre: Artmed; 2005 , p:264-69.

3. Raz A, Buhle J. Typologies of attentional networks. Nature Reviews. 2006, 7:367-79.

4. Lima RF. Compreendendo os mecanismos atencionais. Ciências e Cognição. 2005, 6:113-22.

5. Lima RF, Tabaquim MLM, Ciasca SM. Sistema atencional e funções executivas na infância. In: Ciasca SM, Rodrigues SD, Salgado CA. TDHA: transtorno de déficit de atenção e hiperatividade. Rio de Janeiro: Revinter; 2010:1-20. 
6. Feniman MR. Aplicação do teste de atenção auditiva FC2 em crianças ouvintes normais [tese]. Bauru: Universidade de São Paulo - Faculdade de Odontologia de Bauru; 2004.

7. Feniman MR, Ortelan RR, Campos CF, Cruz MS, Lauris JRP. A Habilidade de Atenção Auditiva Sustentada em Crianças. ACTA ORL/Técnicas em Otorrinol. 2007, 25(4): 280-284.

8. Mondelli MFCG, Carvalho FRP, Feniman MR, Lauris JRP. Perda auditiva leve: desempenho no Teste da Habilidade de Atenção Auditiva Sustentada. Pró-Fono Rev de Atual Cient. 2010, 22(3):245-50.

9. Lemos ICC, Feniman MR. Teste de Habilidade de Atenção Auditiva Sustentada (THAAS) em crianças de sete anos com fissura labiopalatina. Braz. J. Otorhinolaryngol. 2010, 76(2):199-205.

10. Souza SRB. Avaliação as atenção e memória operacional fonológica em indivíduos com síndrome velocardiofacial. [dissertação]. Bauru: Universidade de São Paulo- Faculdade de Odontologia de Bauru; 2009.

11. Duarte TF, Maximino LP, Feniman MR (in press 2011). A Habilidade de atenção auditiva sustentada em crianças com fissura- labiopalatina e transtorno fonológico. Revista Sociedade Brasileira de Fonoaudiologia.

12. Keith RW. ACPT: Auditory continuous performance test. San Antonio, TX, Psychological Corporation, 1994.

13. Tillery KL, KatzJ, Keller WD. Effects of Methylphenidate (Ritalin) on auditory performance in children with attention and auditory processing disorders. J Speech, Lang Hear Res. 2000, 43(4):893-901.

14. Jerger J. Clinical experience with impedance audiometry. Arch Otolaryngol. 1970, 92:3111-24.

15. Northern JL, Downs MP. Audição em crianças. São Paulo: Manole; 1989.

16. Lopes ES. Pacotico, versão 4.6: pacotinho estatístico [CDROM]. Bauru: Faculdade de Odontologia de Bauru, Universidade de São Paulo; 2007.

17. Seidel WT, Joschko M. Evidence of difficulties in sustained attention in children with ADDH. J Abnorm Child Psychol. 1990, 18(2):217-29.

18. Chermak GD, Montgomery MJ. Form equivalent of selective auditory attention test administered to 6-year-old children. ASHA. 1992, (35):661-5.
19. Picolini MM, Stivanin D, Sampaio AR, Salvador KK, Lauris JRP, Feniman MR. Atenção Auditiva: Período do Dia e Tipo de Escola. Arq. Int. Otorrinolaringol. / Int. Arch. Otorhinolaryngol. 2010, 14(2):174-79.

20. Gale A, Lynn R. A developmental study of attention. Br J Educ Psychol. 1972, 42(3):260-6.

21. Brito GNO, Pinto RCA, Lins MFC. A behavioral assessment scale for attention deficit disorder in brazilian children based on DSM-IIIR criteria. J Abnorm Child Psychol. 1995, 23(4):509-20.

22. Pineda D, Ardila A, Rosselli M, Arias BE, Henao GC, Gomes LF, et al. Prevalence of. Attention-deficit/hyperactivity disorders symptoms in 4- to 17-year-old children in the general population. J Abnorm Child Psychol. 1999, 27(6):455-62.

23. Hartung CM, Willcutt EG, Lahey BB, Pelham WE, Loney J, Stein MA, Keenan K. Sex differences in young children who meet criteria for attention deficit hyperactivity disorder. J Clin Child Adolesc Psychol. 2002, 31(4):45364.

24. Groot AS, Sonneville LMJ, Stins JF, Boomsma DI. Familial influences on sustained attention and inhibition in preschoolers. J Chil Psychol Psychiat. 2004, 45(2):306-14.

25. Rhee SH, Waldman ID. Etiology of sex differences in the prevalence of ADHD: an examination of inattention and hyperactivity-impulsivity. Am J Med Genet. 2004, 127B(1):60-4.

26. QueirozDS, Momensohn-Santos M. Diferenças funcionais entre o córtex auditivo primário de homens e mulheres. Rev Distúrb Comun. 2009, 21(1): 107-9.

27. Lin CCH, Hsiao CK, Chen WJ. Development of sustained attention assessed using the continuous performance test among children 6-15 years of age. J Abnorm Child Psychol. 1999, 27(5):403-12.

28. Biederman J, Mick E, Faraone SV, Braaten E, Doyle A, Spencer T, Wilens TE, Frazier E, Johnson MA. Influence of gender on attention deficit hyperactivity disorder in children referred to a psychiatric clinic. Am J Psychiatry. 2002, 159(1):36-42.

29. McGee R, Williams S, Feehan M. Attention deficit disorder and age of onset of problems behaviors. J Abnorm Child Psychol. 1992, 20(5):487-502.

30. Riccio CA, Cohen MJ, Hynd GW, Keith RW. Validity of the Auditory Continuous Test in differentiating central 
processing auditory disorders with and withot ADHD. J Learn Disabil. 1996, 29:561-6.

31. Feniman MR. Central auditory processing disorder in attention deficit hyperactivity disorder, and language-based learning impairment: a normative study. Cincinnati University of. Cincinnati, 1997. (Relatório final CNPq período Dezembro/96 à Novembro/97 - processo no 201175/96-7 (NV).

32. Medwetsky L. Central auditory processing testing: a battery approach. In: Katz J, Burkard RF, Medwetsky L. eds. Handbook of Clinical Audiology. Baltimore, Williams \& Wilkins, 2002. p.510-24.

33. Hagelthorn KM, Hiemenz JR, Pillion JP, Mahone EM. Age and task parameters in continuous performance tests for preschoolers. Percept Mot Skills. 2003, 96 (3 Pt 1):97589.

34. Mahone ME. Measurement of attention and related functions in the preschool child. Ment Retard Dev Disabil Res Rev. 2005, 11(3):216-25.
35. Helene AF, Xavier FG. A construção da atenção a partir da memória. Rev Bras Psiquiatr. 2003, 25(Supl II):12-20.

36. Yusuf S, Collins R, Peto R. Why do we need some large, simple randomized trials? Statistics in Medicine. 1984, 3:40920.

37. Collins R, Peto R, Gray R, Parish S. Large-scale randomized evidence: trials and overviews. In: Weatherall DJ, Ledingham JGG, Warrell DA. editors. Oxford Textbook of Medicine. 3rd ed. Oxford: Oxford University Press. 1996, 21-32.

38. Weissberg R, Ruff HA, Lawson KR. The usefulness of reaction time tasks in studying attention and organization of behavior in young children. J Dev Behav Pediatr. 1990, 11(2):59-64.

39. Duarte J L, Alvarenga KF, Costa OA. Potencial cognitivo p300 realizado em campo livre: aplicabilidade do teste. Rev Bras Otorrinolaringol. 2004, 70(6):780-5. 